Prepared in cooperation with the Task Force for Business and Stability Operations, Department of Defense

\title{
A Comprehensive Population Dataset for Afghanistan Constructed Using GIS-Based Dasymetric Mapping Methods
}

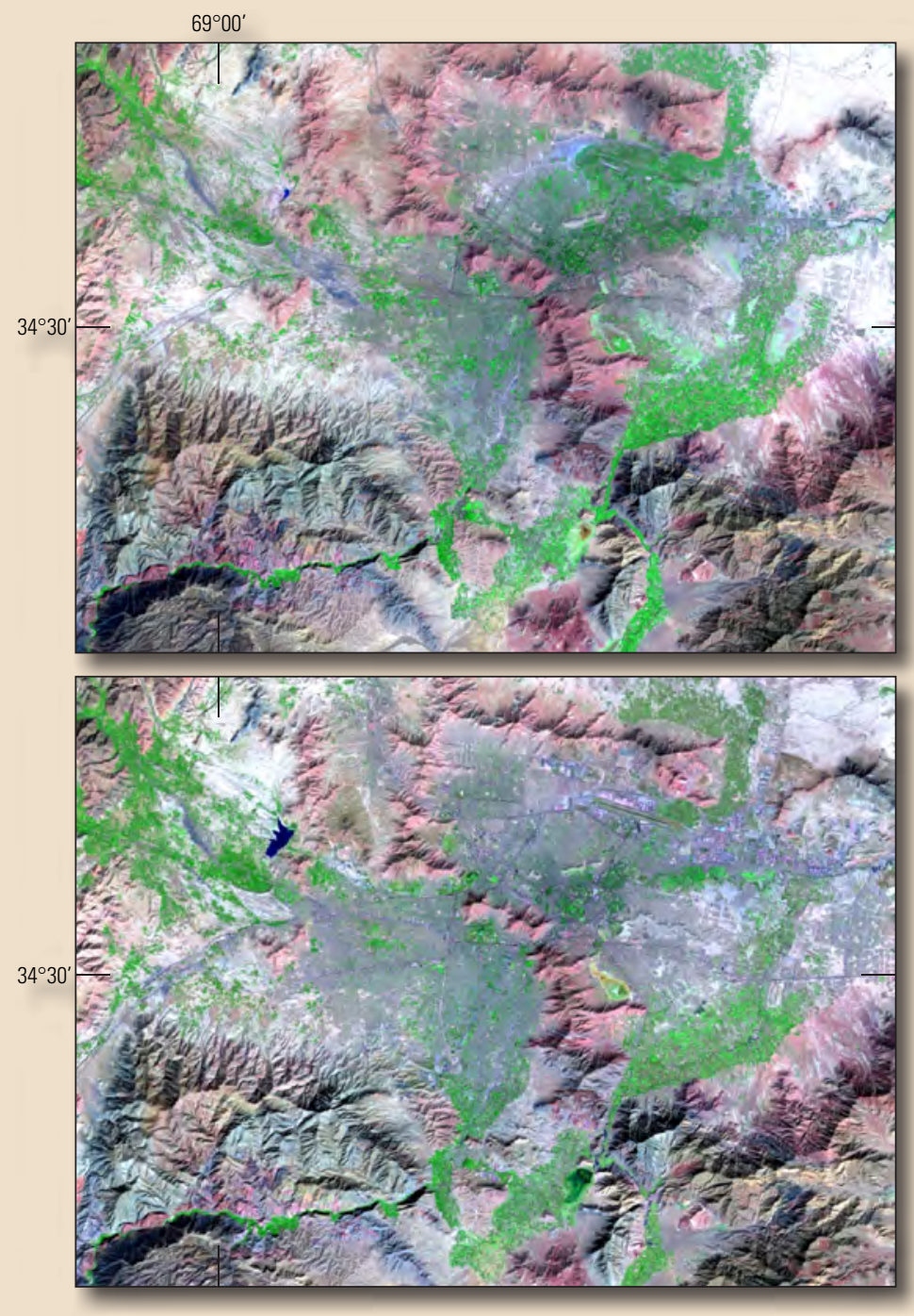

Scientific Investigations Report 2013-5238 USGS Afghanistan Project Product No. 261 
Cover images. Landsat images showing the growth of Kabul, Afghanistan, and vicinity from September 26, 2001 (top image), to 0ctober 21, 2013 (bottom image). Area shown in images is 38 kilometers (vertical distance) by 28 kilometers (horizontal distance). 


\section{A Comprehensive Population Dataset for Afghanistan Constructed Using GIS-Based Dasymetric Mapping Methods}

By Allyson L. Thompson and Bernard E. Hubbard

Prepared in cooperation with the Task Force for Business and Stability

Operations, Department of Defense

Scientific Investigations Report 2013-5238

USGS Afghanistan Project Product No. 261 


\title{
U.S. Department of the Interior SALLY JEWELL, Secretary
}

\section{U.S. Geological Survey Suzette M. Kimball, Acting Director}

\author{
U.S. Geological Survey, Reston, Virginia: 2014
}

For more information on the USGS - the Federal source for science about the Earth, its natural and living resources, natural hazards, and the environment, visit http://www.usgs.gov or call 1-888-ASK-USGS.

For an overview of USGS information products, including maps, imagery, and publications, visit http://www.usgs.gov/pubprod

To order this and other USGS information products, visit http://store.usgs.gov

Any use of trade, firm, or product names is for descriptive purposes only and does not imply endorsement by the U.S. Government.

Although this information product, for the most part, is in the public domain, it also may contain copyrighted materials as noted in the text. Permission to reproduce copyrighted items must be secured from the copyright owner.

Suggested citation:

Thompson, A.L., and Hubbard, B.E., 2014, A comprehensive population dataset for Afghanistan constructed using GIS-based dasymetric mapping methods: U.S. Geological Survey Scientific Investigations Report 2013-5238, 21 p., http://dx.doi.org/10.3133/sir20135238.

ISSN 2328-0328 (online) 


\section{Contents}

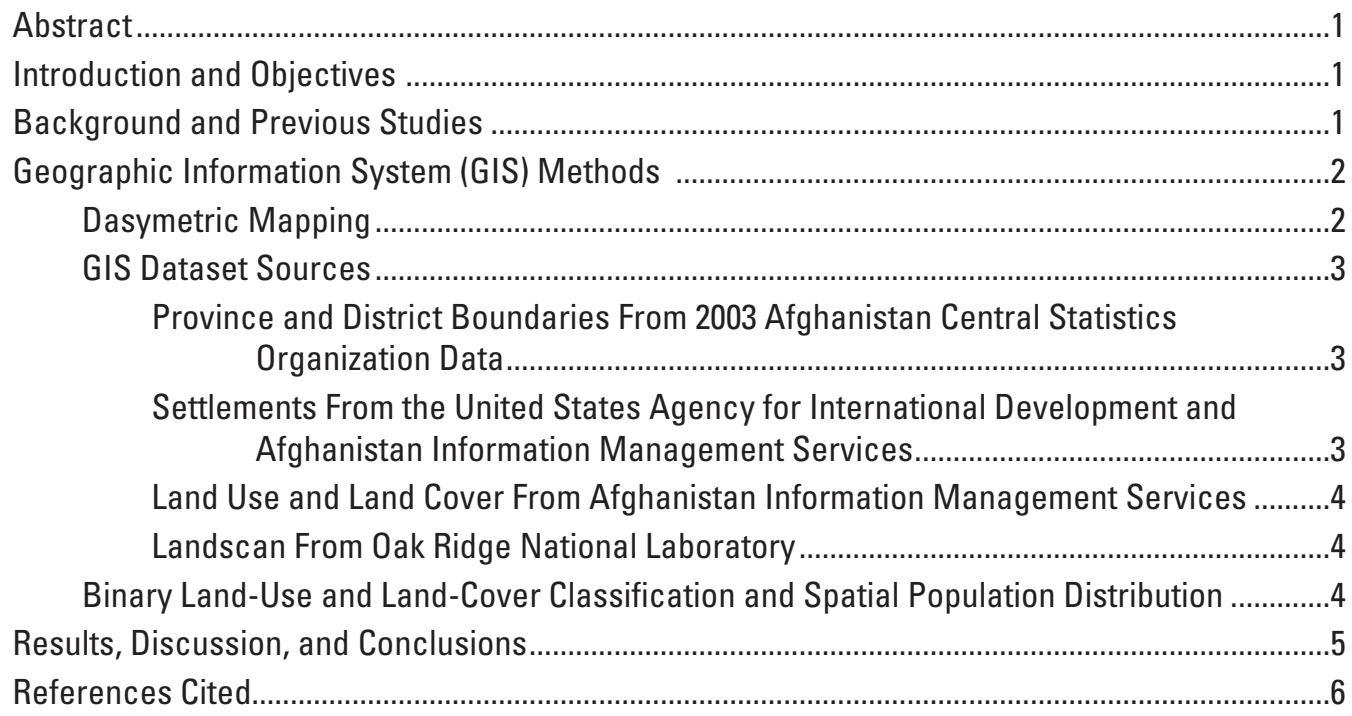

\section{Figures}

[Figures are at end of report]

1. Choropleth map showing the 2003 population of Afghanistan, by province ....................7

2. Choropleth map showing the 2003 population of Afghanistan, by district........................8

3. Map showing the ambient population distribution within Afghanistan based on 2005 Landscan raster data, the distribution of major settlements, and hydrologic features

4. Choropleth map showing population density within Afghanistan, by province, derived from the 2003 data on population by province shown in figure 1 .......................10

5. Choropleth map showing population density within Afghanistan, by district, derived from the 2003 data on population by district shown in figure 2.........................11

6. Land-use and land-cover classification map of Afghanistan, based on data from the Afghanistan Information Management Services.

7. Map of Afghanistan showing inhabited and uninhabited areas, which were based on land-use and land-cover classifications...

8. Map of Afghanistan showing inhabited land by land-use and land-cover classification

9. Map of the 2003 population of Afghanistan, by province, compiled using dasymetric mapping methods

10. Map of the 2003 population of Afghanistan, by district, compiled using dasymetric mapping methods

11. Map of the 2003 population density within Afghanistan, by province, compiled using dasymetric mapping methods.

12. Map of the $\mathbf{2 0 0 3}$ population density within Afghanistan, by district, compiled using dasymetric mapping methods.

13. Maps of the Kabul basin of Afghanistan comparing the results of dasymetric population mapping with Landscan population mapping 


\section{Conversion Factors}

\begin{tabular}{|c|c|c|}
\hline Multiply & By & To obtain \\
\hline \multicolumn{3}{|c|}{ Length } \\
\hline meter (m) & 3.281 & foot $(\mathrm{ft})$ \\
\hline kilometer (km) & 0.6214 & mile (mi) \\
\hline \multicolumn{3}{|c|}{ Area } \\
\hline square kilometer $\left(\mathrm{km}^{2}\right)$ & 0.3861 & square mile $\left(\mathrm{mi}^{2}\right)$ \\
\hline
\end{tabular}

Horizontal coordinate information is referenced to the World Geodetic System of 1984 (WGS84).

The resolution of pixels in spatial datasets follows the conventions used in the spatial data and modeling communities. The format is "n-meter resolution," where $\mathrm{n}$ is a numerical value for the length. The usage translates into a pixel with a length of $\mathrm{n}$ on all sides that covers an area of $\mathrm{n}$ meters $\times \mathrm{n}$ meters.

\section{Acronyms}

ASTER Advanced Spaceborne Thermal Emission and Reflection Radiometer

AVHRR Advanced Very High Resolution Radiometry (satellite)

AIMS Afghanistan Information Management Services

CSO Central Statistics Organization

DMSP Defense Meteorological Satellite Program

DEM digital elevation model

DTED Digital Terrain Elevation Data

GIS Geographic Information System

GLCC Global Land Cover Characteristics (database)

MAU modifiable area unit

NGA National Geospatial Intelligence Agency

NIMA (formerly the) National Intelligence Mapping Agency (now NGA)

ORNL Oak Ridge National Laboratory

SRTM Shuttle Radar Topography Mission

TM (Landsat) Thematic Mapper

USAID United States Agency for International Development

USDMA (formerly the) United States Defense Mapping Agency (now NGA)

VMAP Vector-smart Map 


\title{
A Comprehensive Population Dataset for Afghanistan Constructed Using GIS-Based Dasymetric Mapping Methods
}

\author{
By Allyson L. Thompson and Bernard E. Hubbard
}

\begin{abstract}
This report summarizes the application of dasymetric methods for mapping the distribution of population throughout Afghanistan. Because Afghanistan's population has constantly changed through decades of war and conflict, existing vector and raster GIS datasets (such as point settlement densities and intensities of lights at night) do not adequately reflect the changes. The purposes of this report are (1) to provide historic population data at the provincial and district levels that can be used to chart population growth and migration trends within the country and (2) to provide baseline information that can be used for other types of spatial analyses of Afghanistan, such as resource and hazard assessments; infrastructure and capacity rebuilding; and assisting with international, regional, and local planning.
\end{abstract}

\section{Introduction and Objectives}

Understanding the population of Afghanistan and its distribution has been a difficult task because the last Afghan census, held in 1979, was never completed after the Soviet invasion. Although Afghanistan's Central Statistics Organization (CSO) attempts to collect, compile, and analyze current population data by provincial and district administrative units, the continual fluctuation of the population and the changing administrative boundaries pose a challenge to accurately collecting such data.

This paper presents the methodological framework and results for constructing a comprehensive population dataset for Afghanistan using a fully automated, dasymetric mapping method. Dasymetric mapping was invented and developed by Benjamin Semenov-Tian-Shansky in St. Petersburg, Russia, during the period from 1911 to the early 1920s and culminated in the completion of the "Dasymetric Map of European Russia" (Petrov, 2012). The technique generally relies on spatial interpolation to distribute population (and (or) any other numerically valued map attribute) in a manner similar to that of an isopleth map (where contour lines of equal value or density are used) instead of a choropleth map (which is a generalized representation of numerical values) (Petrov, 2012).

For this study, historic population data were compiled according to both province- and district-level boundaries and displayed thematically as choropleth maps. Using a geographic information system (GIS), dasymetric mapping techniques were then applied to show the distribution of population at finer spatial scales by making use of land-use and land-cover polygon data and a raster layer compiled from nighttime-light-intensity data and high-resolution orthoimagery (Elvidge and others, 1997; Dobson and others, 2000; Bhaduri and others, 2002); the raster layer depicts the distribution of roads, agricultural fields, and settlement patterns. The resulting modeled distributions of Afghanistan's population are therefore new estimates that may be useful in ongoing and future spatial analysis activities, such as resource and hazard assessments.

\section{Background and Previous Studies}

Provinces are the primary administrative divisions of Afghanistan. As of 2004, there were 34 recognized provinces. Districts are the secondary administrative divisions of Afghanistan. The number of districts within Afghanistan has fluctuated over the years. Before 1979, there were 325 districts, which later increased to 329 districts during the civil war period of the 1990s. In 2004, the districts increased again to 397 after a major reorganization of provinces. As of June 2005, the Afghan Ministry of the Interior recognized 398 districts, divided among 34 provinces. This number may change yet again, during future anticipated administrative reorganizations. On the basis of a nationwide survey conducted by Afghanistan's CSO (2012), 24.5 million Afghans were living in the country in 2009. Of these, 5.7 million people were 
reported to be living in urban areas and the rest in rural areas. As of 2011, the total population was estimated to be about 31 million people (CSO, 2012).

According to Bielecka (2005), population mapping in Afghanistan (and other places around the world) serves two general purposes: (1) "to cartographically portray the extent and density of population across an area of interest" and (2) to "derive a quantitative estimation of population density for use in subsequent spatial analytical modeling tasks." The most commonly and traditionally used population map is the choropleth map, which is a type of thematic map in which areas are shaded or patterned based on some proportion of the statistical measurement being displayed as variable. Choropleth maps are simple to construct, especially with the aid of automated GIS mapping software. The use of choropleth maps, however, is limited when performing more detailed GIS spatial analysis, such as determining the most accurate distribution of people and population densities across vector polygons and (or) raster cells. In the case of Afghanistan, most people live in the flatter areas and in gently sloping valleys, where they have better access to water than along the steep mountainsides, which are generally smoothed over when depicted on choropleth maps. Openshaw (1984) describes this condition as the modifiable areal unit (MAU) problem, whereby data (census population statistics) aggregated at the scale of modifiable area units (for example, changing province and district boundaries) commonly provide poor representations of the distribution of such data at scales smaller than the MAU. For example, in Afghanistan, choropleth maps of population distributed by province and district (figs. 1,2) give the impression that the population is distributed homogenously throughout each areal unit, even though large parts of each province and district actually may be uninhabited. In Afghanistan, human populations are generally concentrated within relatively small numbers of villages and towns that are typically clustered around available sources of water (fig. 3); therefore, the choropleth maps showing total population attributed by province or district mix units representing inhabited areas with units representing uninhabited areas (figs. 4, 5).

Langford and Unwin (1994) further explain that the MAU is a major obstacle when attempting to map population densities because "any measurement of population density is inherently linked to the area over which it is calculated;" therefore, "depending on the boundaries of (the polygon) space chosen, it is possible to obtain virtually any density measure" (figs. 4, 5). In the case of Afghanistan, figures 4 and 5 show how population density is biased by the areas of individual provinces and districts over which they are calculated (as explained by Langford and Unwin, 1994). If the areal extents and (or) boundaries of individual provinces and districts change with future political and administrative reorganizations, then the distribution of population density values will undoubtedly change. When the 2003 distribution of population densities by province (fig. 4) and district (fig. 5) are compared to the 2005 Landscan ambient population data (fig. 3), it becomes clear that population density values are relatively overestimated in the larger provinces and districts surrounding the smaller capital city district of Kabul, and relatively underestimated in the larger but also populous provinces such as Kandahar, which contains Afghanistan's second largest city and a large number of settlements (towns and villages) and district centers along the Helmand River valley (figs. 1, 2). Langford and Unwin (1994) also note that choropleth maps create the erroneous impression that population density abruptly changes at administrative borders, when in reality these changes tend to be gradational across such boundaries.

Although the Landscan ambient population data are also based on dasymetric mapping methods (Dobson and others, 2000; Bhaduri and others, 2002), they are distributed as raster data that are limited to $1 \times 1-\mathrm{km}$ grid cells and therefore do not necessarily represent every year of the entire historic population dataset compiled for this study. To solve this problem for Afghanistan, dasymetric mapping methods were applied in this study in order to distribute the population in a more representative manner than the choropleth maps, which are restricted by province and district polygon areas. This distribution is based on a binary classification of inhabited and uninhabited land-use classes together with census-attributed province and district data, settlement density data, and the coarser scale (1-km resolution) Landscan rendition of ambient population; the latter is based on a variety of remote-sensing and ancillary data sources (Dobson and others, 2000; Bhaduri and others, 2002), which will be discussed in more detail in the GIS methods section.

\section{Geographic Information System (GIS) Methods}

\section{Dasymetric Mapping}

Dasymetric mapping is a form of areal interpolation that transforms data from one set of units to another with the assistance of supplementary data. Wright (1936) was one of the first cartographers to popularize dasymetric mapping by demonstrating how population density maps of the Cape Cod, Massachusetts, area could be refined by (1) accounting for uninhabited or sparsely populated areas characterized by certain geologic features and land-cover types and (2) subdividing townships into developed tracts on the basis of estimated changes in housing densities across each township. He developed dasymetric cartography as a means to more accurately map population density by reassigning data between MAUs (townships divided into subdivisions) and incorporating ancillary map information (such as uninhabited marshland, sand dunes, and uncultivated glacial moraine deposits) to assist in the final cartographic redistribution and representation of population density values.

Following the work of Wright (1936) and Langford and Unwin (1994), Eicher and Brewer (2001) explored and compared several different methods of producing dasymetric 
maps, such as the "three-class" method, the "limiting variable" method, a grid-based interpolation method, and a polygonbinary method for interpolating and distributing population and population density values across MAUs. The "three-class" method typically requires a weighting scheme for the redistribution of population among up to three aggregated land-use classes (for example, Mennis, 2003), whereas the "limiting variable" method is similar to the "binary classification" method of Wright (1936) in that the inhabited and uninhabited land-use or land-cover categories must first be identified and then the population density values interpolated between the two vector (or grid) "surfaces" (Langford and Unwin, 1994). Eicher and Brewer (2001) evaluated the accuracy and errors of each method and concluded that Wright's (1936) original "limiting variable" technique produced maps with the highest accuracy and least amount of error, although reducing the amount of error was not found to be statistically any more significant than the errors yielded by using the other methods.

A survey of recent literature indicates that applications of dasymetric mapping methods to population and population density maps and studies are sparse (Mennis, 2003; Bielecka, 2005); however, of the methods compared and discussed by Eicher and Brewer (2001), the binary classification method (discussed in detail in a later section) appears to be the most commonly applied dasymetric mapping method. When landuse or land-cover information is provided as ancillary data, different classes may be designated as either inhabitable or uninhabitable, such that the population can be better distributed into the most habitable areas. Bielecka (2005) noted that this simple binary classification of "inhabited" versus "uninhabited" improved the accuracy of the traditional choropleth maps of population previously used to depict the distribution of population throughout Podlaskie County, Poland.

In addition to their evaluation of the binary classification (or limiting variable) method, Langford and Unwin (1994) also suggested raster alternatives to the conventional choropleth population maps. For example, they suggested the use of remotely sensed data sources such as Landsat Thematic Mapper (TM) imagery to help model population density as a continuous raster "surface" of land-use and land-cover types that can be used as an input layer to aid with interpolation within a GIS. In their case, the authors aggregated their dasymetric population estimates of northern Leicestershire, United Kingdom, across a 1-km resolution grid of binary raster cell values designated as either "habited" or "uninhabited."

The existing vector GIS layers of the province and district boundaries of Afghanistan (Mihalasky and others, 2007) have been attributed with historical population data (figs. 1,2), which are available for download as GIS shape file layers accompanying this report; however, these historic population data cannot be used for more detailed spatial analyses at scales finer than the largest district (Chahar Burjak district in Nimruz province at $21,058 \mathrm{~km}^{2}$ ) or the smallest province (Kapisa province, which contains six smaller districts for a total of $\left.1,842 \mathrm{~km}^{2}\right)$. In this report, the binary dasymetric mapping method was chosen in order to map the distribution of population across Afghanistan more accurately by interpolating census-derived population statistics across inhabited and uninhabited land-use and land-cover classes. As such, we use the ancillary raster information as dasymetric mapping inputs in the form of the Landscan ambient population data (fig. 3), land-use and land-cover polygon vectors (fig. 6), and settlement point datasets (shown on fig. 3), described further in the following section. ArcMap v. 9.3.1 (ESRI, 2012) was used to implement the methodology, as described below.

\section{GIS Dataset Sources}

Four datasets were used in our dasymetric population distribution analysis. Each is described in the following sections.

\section{Province and District Boundaries From 2003 Afghanistan Central Statistics Organization Data}

The shape file showing Afghanistan's province boundaries consisted of 34 separate provinces, each attributed with population data from the 2003, 2006, and 2011 CSO reports; the 2003 population is shown in figure 1 . The district shape file consisted of 329 districts with population data attributed from the 1990, 1998, 2000, and 2003 CSO reports; the 2003 population is shown in figure 2 . The 2003 population data were chosen for this analysis because 2003 is the only year for which data were present for both the province and district shape files (figs. 1, 2). Both the province and the district boundary shape files were originally digitized by the Afghanistan Information Management Services (AIMS) and are available as part of the U.S. Geological Survey (USGS) Preliminary Non-Fuel Mineral Resource Assessment of Afghanistan (Mihalasky and others, 2007; Peters and others, 2007).

\section{Settlements From the United States Agency for International Development and Afghanistan Information Management Services}

Data showing settlements in Afghanistan were originally derived from a vector point shape file, also acquired from the USGS Preliminary Non-Fuel Mineral Resource Assessment of Afghanistan (Mihalasky and others, 2007; Peters and others, 2007); however, the file was modified to show changes in province centers, district centers, and to the capital city of Kabul since the original version was compiled (fig. 1). These changes include new province and district centers and (or) consolidations or relocations of old province and district centers. These settlement points were originally digitized by staff of the United States Agency for International Development (USAID) on the basis of (1) 1:100,000-scale maps compiled by the former Defense Mapping Agency (DMA; a former bureau within the U.S. Department of Defense) between 1967 and 1988 and (2) 1:50,000 scale Soviet-era Russian 
topographic maps, which include locations of villages and other cultural features.

\section{Land Use and Land Cover From Afghanistan Information Management Services}

The data for the land-use and land-cover shape file (fig. 6) were originally acquired from the AIMS Web site (AIMS, 2012), and can also be found in the USGS Preliminary NonFuel Mineral Resource Assessment of Afghanistan (Mihalasky and others, 2007; Peters and others, 2007). The land-use and land-cover polygon vector dataset consists of the following 21 classes:

- Regenerated, old growth forests or high shrubs

- Fruit trees

- Gardens

- Irrigated and intensively cultivated (1 crop per year)

- Irrigated and intensively cultivated ( 2 crops per year)

- Irrigated and intermittently cultivated

- Marshland (permanently inundated)

- Marshland (seasonal)

- Natural forest (closed cover)

- Natural forest (open cover)

- Permanent snow

- Pistachio forest

- Rainfed crops (flatlying areas)

- Rainfed crops (sloping areas)

- Rangeland (grassland, forbs, low shrubs)

- Rock outcrop or bare soil

- Sand-covered areas

- Sand dunes

- Settlements

- Vineyards

- Water bodies

\section{Landscan From Oak Ridge National Laboratory}

The 2005 Landscan global dataset, a product of the Oak Ridge National Laboratory (ORNL, 2005), uses two remotesensing data sources (panchromatic image-validated land use and land cover and nighttime light density) and other ancillary input GIS datasets such as proximity to roads, topographic slope, urban density, and available census data at the province and district (or subprovince) levels to show the distribution of ambient population 1-km (about 30 arc second) spatial resolution (Dobson and others, 2000; Bhaduri and others, 2002; fig. 4). In this case, ambient population is based on residential population redistributed by dasymetric manipulation to $1-\mathrm{km}$ grid cells based on probability coefficients that vary from region to region, depending on the relative weighting and variation of such factors as urban density and nighttime lights between industrialized and energy-poor nations.

Ancillary data, such as roads, used for the 1998 Landscan dataset were derived from the 1:1,000,000 scale Vector-smart Map of the world (VMAP; NGA, 2013) compiled by the National Geospatial-Intelligence Agency (NGA), whereas topographic data were derived from NGA's level 0 (30 arc second) Digital Terrain Elevation Data (DTED; NGA, 2013) (Dobson and others, 2000, Bhaduri and others, 2002). The Defense Meteorological Satellite Program (DMSP) is one of several sources of nighttime light emissions data from the Earth's surface at 1-km spatial resolution (Elvidge and others, 1997), which was used as an input for Landscan ambient population modeling (Dobson and others, 2000; Bahduri and others, 2002). This same raster GIS dataset covering Afghanistan can also be found in the USGS Preliminary Non-Fuel Mineral Resource Assessment of Afghanistan (Peters and others, 2007; Mihalasky and others, 2007), but is only available for 1998. Input land-use and land-cover data for the Landscan ambient population modeling were based on the USGS Global Land Cover Characteristics (GLCC; USGS, 2013) database and were derived from Advanced Very High Resolution Radiometer (AVHRR) satellite imagery (Loveland and others, 1991).

Dobson and others (2000) noted that more accurate and higher resolution data would be used as inputs for future versions of the Landscan ambient population dataset. Indeed, the Landscan ambient population data have been revised yearly by ORNL since 1998 as newer and more accurate national and provincial census data and remote-sensing datasets are incorporated. For example, the Shuttle Radar Topography Mission (SRTM) and Advanced Spaceborne Thermal Emission and Reflection Radiometer (ASTER) digital elevation models (DEMs) now provide global topographic data at approximately $90-\mathrm{m}$ and $30-\mathrm{m}$ spatial resolution, respectively, which can be used to derive topographic slope attributes at a higher resolution than the 1-km DTED data used in the original 1998 Landscan data; however, Landscan population data are only distributed at a spatial resolution of no less than $1 \mathrm{~km}$, and yearly revised data products cannot be used for detecting population change (Bhaduri and others, 2002).

\section{Binary Land-Use and Land-Cover Classification and Spatial Population Distribution}

After the population data provided by the CSO was tabulated and joined with the existing province and district 
shape files, the topology of the shape files was corrected for errors (dangling arcs and small outlier polygons that were not connected to any province or district boundary), and the dataset was converted into a geodatabase. The binary dasymetric method described by Langford and Unwin (1994), Eicher and Brewer (2001), and Bielecka (2005) was then applied.

By using the AIMS land-use and land-cover shape file, a new field was first created to attribute whether or not a particular land class was inhabited or uninhabited (fig, 7). The new field was based on both the land-use or land-cover classification (fig. 6), the presence of settlements (from overlaying a point shape file; fig. 3), and the 2005 ambient population distribution depicted by the Landscan data (fig. 3). The landuse and land-cover classifications that were determined to be inhabited included settlements, irrigated and intensively cultivated ( 1 crop per year), irrigated and intensively cultivated ( 2 crops per year), irrigated and intermittently cultivated, rainfed crops (sloping areas), fruit trees, gardens, and vineyards (fig. 8).

After the AIMS land-use and land-cover dataset had been attributed as either inhabited or uninhabited, the data were then overlain with the existing population-attributed province and district boundary shape files using the Union tool within Arc Toolbox. As a result, the two new existing shape files were then symbolized to show the 2003 population distribution within each province and district, respectively, within existing settled locations (figs. 9, 10).

\section{Results, Discussion, and Conclusions}

The resulting population distribution maps of Afghanistan (figs. 9, 10) demonstrate the effective use of dasymetric mapping techniques, which merged both raster-derived data (Landscan) and vector-based data (land-use, land-cover, and settlements) to produce a more realistic map. The final results match well with the input pattern of population distribution depicted by the settlement point data and the Landscan ambient population (fig. 3). An even better visual correlation with the population distribution depicted in the Landscan ambient population is achieved after the dasymetric population distributions are normalized by their respective province and district areas to yield maps of dasymetric population density distributed across province and district boundaries (figs. 11, 12, respectively). In this case, the resulting dasymetric maps of total population and population density (figs. 9 through 12) reflect the population distribution derived from the 2003 CSO statistics rather than the modeled distribution of the 2005 population as reflected in the Landscan ambient population data (fig. 3). The pattern and density of distributed population are similar in both cases and support the observation that Afghanistan's population is and will likely remain concentrated in topographically flatter areas with better access to water.

Throughout the literature, most authors emphasize that the primary advantage of the binary method is its simplicity because it is only necessary to reclassify land use and land cover into two classes: inhabited and uninhabited. Additionally, this process is easy to implement within a GIS and can be replicated as more accurate and current population data are collected. Conversely, they also point out that the main disadvantage of the binary method is its subjectivity because deciding which areas are inhabited and uninhabited is based on patterns of existing land-use, land-cover, and settlementdensity data.

Because of the current geopolitical situation in the country (insurgency and a population that is in a state of flux), it is difficult to verify the accuracy of the dasymetric mapping results. The results, however, can be tested by comparing the resulting dasymetric distribution of population based on binary land-use and land-cover classification (fig. 13A) with the original population distribution modeled in the 2005 Landscan data (fig. 13B). Overall, the dasymetric redistribution of population matches the pattern and distribution of population modeled by the Landscan data. There are, however, some notable differences. First, the dasymetric population map can be considered a hybrid between a true isopleth map (obtained by contouring the Landscan values depicted in figures 3 and $13 B$ ) and the actual choropleth maps (the original population maps coded by province and district shown in figures 1 and 2, respectively). Second, when the ancillary land-use and land-cover information is considered, the dasymetric map allows population to be more accurately contained within smaller polygon units than the maps that portray only province- or district-level statistics. Third, because the Landscan data reduce population data to $1-\mathrm{km}$ resolution, sparsely populated areas become indistinguishable from uninhabited areas. The dasymetric map solves this problem by redistributing the population into smaller and more appropriate land-use and land-cover classes, thus allowing the uninhabited areas to remain unclassified and distinguishable from the areas that are actually inhabited by people.

In reference to the binary method of dasymetric mapping, Langford and Unwin (1994) observed that "it is arbitrary in the sense that there is no obvious scale at which it should be applied," which is why they developed the model of population as a continuous surface. Although this technique could be used for a detailed population analysis at a more localized (subdistrict) level, in the case of Afghanistan, the binary method offers a more realistic estimate of the distribution of the population at the national, provincial, and district scales.

The information produced from the resulting dasymetric population maps ultimately can be used for more detailed spatial analyses of Afghanistan, such as hazard assessments, understanding access to resources, and regional planning to account for future population growth trends. Dasymetric mapping methods can be applied easily to the other years of CSO census data attributed to the province and district shape files accompanying this report. 


\section{References Cited}

Afghanistan Information Management Services, 2012, Afghanistan Information Management Services: Afghanistan Information Management Services Web site at http://www.aims.org.af/, accessed December 1, 2012.

Bielecka, Elzbieta, 2005, A dasymetric population density map of Poland, in Proceedings, Twenty-second Annual International Cartographic Conference, A Coruña, Spain, July 9-16, 2005: Madrid, Spain, Sociedad Española de Cartografia, Fotogrametría y Teledetección 1 CD. (Also available at http://icaci.org/files/documents/ICC proceedings/ICC2005/htm/pdf/oral/TEMA5/Session\%209/ ELZBIETA\%20BIELECKA.pdf.)

Bhaduri, Budhendra, Bright, Edward, Coleman, Phillip, and Dobson, Jerome, 2002, Landscan; Locating people is what matters: Geoinformatics, v. 5, no. 2, p. 34-37.

Central Statistics Organization, 2012, [Afghanistan] Central Statistics Organization Web page [Population Statistics and Statistical Yearbook]: [Afghanistan] Central Statistics Organization Web site at http://www.cso.gov.af/, accessed December 1, 2012 .

Dobson, J.E., Bright, E.A., Coleman, P.R., Durfee, R.C., and Worley, B.A., 2000, Landscan; A global population database for estimating populations at risk: Photogrammetric Engineering and Remote Sensing, v. 66, no. 7, p. 849-857. (Also available online at http://eserv.asprs.org/PERS/2000journal/ jul/2000_jul_849-857.pdf.)

Eicher, C.L., and Brewer, C.A., 2001, Dasymetric mapping and areal interpolation implementation and evaluation: Cartography and Geographic Information Science, v. 28, no. 2, p. 125-138. (Also available online at http://www.tandfonline. com/doi/abs/10.1559/152304001782173727\#preview.).

Elvidge, C.D., Baugh, K.E., Kihn, E.A., Kroehl, H.W., and Davis, E.R., 1997, Mapping city lights with nighttime data from the DMSP Operational Linescan System: Photogrammetric Engineering and Remote Sensing, v. 63, no. 6, p. 727-734. (Also available online at http://eserv.asprs.org/ PERS/1997journal/jun/1997_jun_727-734.pdf.)

ESRI, 2012, ArcMap version 9.3.1, ArcGIS desktop 9.3 help: Redlands, Calif., Environmental Systems Research Institute.

Langford, M., and Unwin, D.J., 1994, Generating and mapping population density surfaces within a geographical information system: The Cartographic Journal, v. 31, no. 1, p. 21-26. (Also available online at http://dx.doi.org/10.1179/ 000870494787073718.)

Loveland, T.R., Merchant, J.W., Ohlen, D.O., and Brown, J.F., 1991, Development of a land-cover characteristics database for the conterminous U.S.: Photogrammetric Engineering and Remote Sensing, v. 57, no. 11, p. 1453-1463. (Also available online at http://eserv.asprs.org/PERS/1991journal/ nov/1991_nov_1453-1463.pdf.)
Mennis, Jeremy, 2003, Generating surface models of population using dasymetric mapping: The Professional Geographer, v. 55, no. 1, p. 31-42. (Also available online at http://onlinelibrary.wiley.com/ doi/10.1111/0033-0124.10042/abstract.).

Mihalasky M.J., Doebrich, J.L., Wahl, R.W., Ludington, S.D., Orris, G.J., Bliss, J.D., Sutphin, D.M., Schruben, P.G., Bolm, K.S., Hubbard, B.E., Mars, J.C., Peters, S.G., Wandrey, C.J., and Chirico, Pete, 2007, Geographic information system (GIS) to accompany the non-fuel mineral resource assessment of Afghanistan, appendix 1 of Peters, S.G., Ludington, S.D., Orris, G.J., Sutphin, D.M., Bliss, J.D., and Rytuba, J.J., eds., and the U.S. Geological SurveyAfghanistan Ministry of Mines Joint Mineral Resource Assessment Team, Preliminary Non-Fuel Mineral Resource Assessment of Afghanistan: U.S. Geological Survey OpenFile Report 2007-1214 (version 1.1), available only online at http://pubs.usgs.gov/of/2007/1214/\#GIS.

National Geospatial-Intelligence Agency, 2013, NGA Raster Roam [VMAP and DTED data]: National GeospatialIntelligence Agency Web site at http:/geoengine.nga.mil/ geospatial/SW_TOOLS/NIMAMUSE/webinter/rast_roam. html, accessed December 9, 2013.

Oak Ridge National Laboratory, 2005, Landscan population data: Oak Ridge National Laboratory dataset at http://web. ornl.gov/sci/landscan/, accessed in 2006.

Openshaw, Stan, 1984, The modifiable areal unit problem: Concepts and Techniques in Modern Geography, v. 38, p. 41.

Petrov, Andrey, 2012, One hundred years of dasymetric mapping; Back to the origin: The Cartographic Journal, v. 49, no. 3, p. 256-264. (Also available online at http://www.ingentaconnect.com/content/maney/ caj/2012/00000049/00000003/art00007.)

Peters, S.G., Ludington, S.D., Orris, G.J., Sutphin, D.M., Bliss, J.D., and Rytuba, J.J., eds., and the U.S. Geological Survey-Afghanistan Ministry of Mines Joint Mineral Resource Assessment Team, 2007, Preliminary non-fuel mineral resource assessment of Afghanistan: U.S. Geological Survey Open-File Report 2007-1214, 822 p. plus data files, available only online at http://pubs.usgs.gov/ of/2007/1214/.

U.S. Geological Survey, 2013, Global Land Cover Characterization database: U.S. Geological Survey Web site at http://edc2.usgs.gov/glcc/glcc.php, accessed December 9, 2013.

Wright, J.K., 1936, A method of mapping densities of population with Cape Cod as an example: Geographical Review, v. 26, no. 1, p. 103-110. (Also available online at http://www.jstor.org/stable/209467.) 


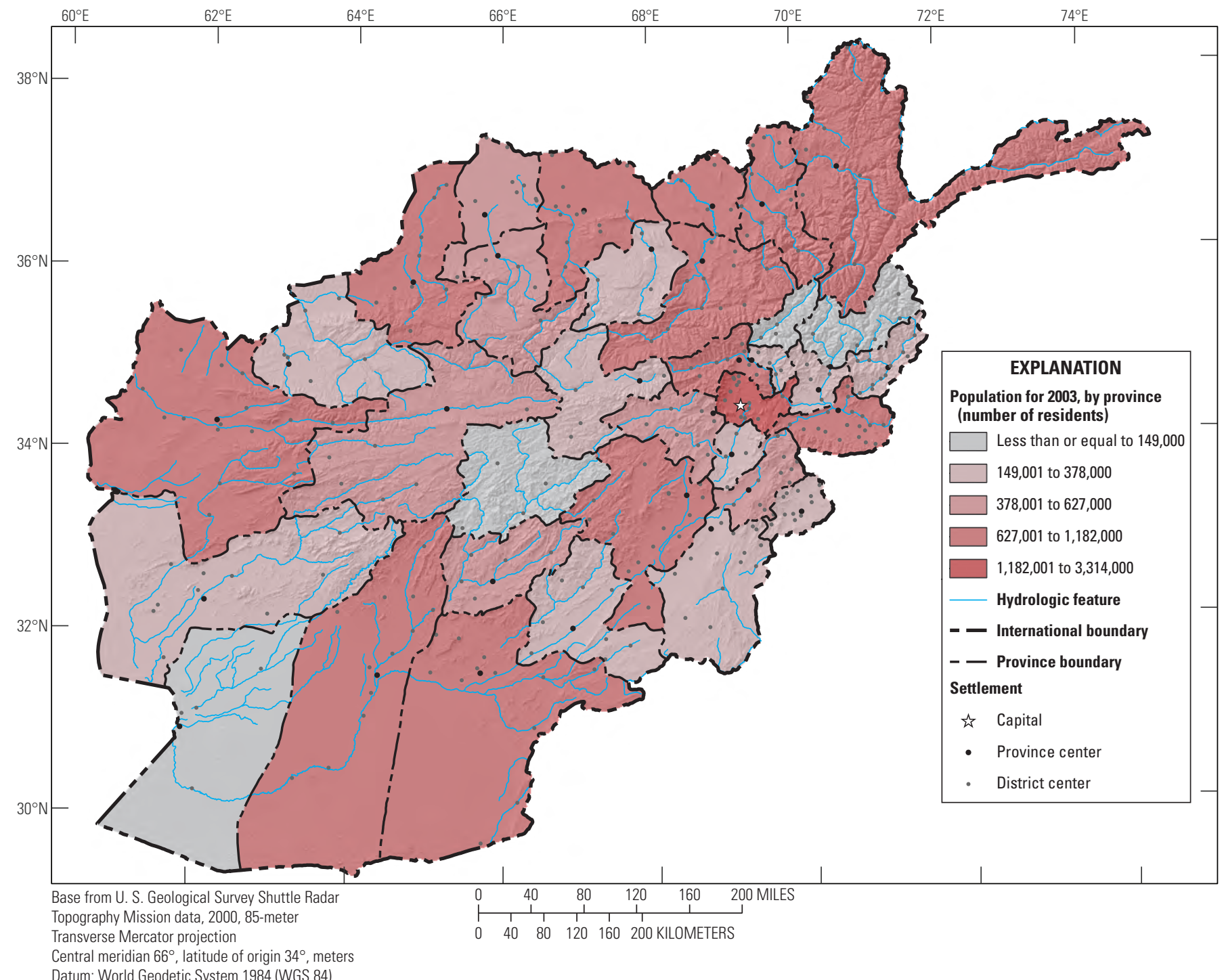

Figure 1. Choropleth map showing the 2003 population of Afghanistan, by province. 


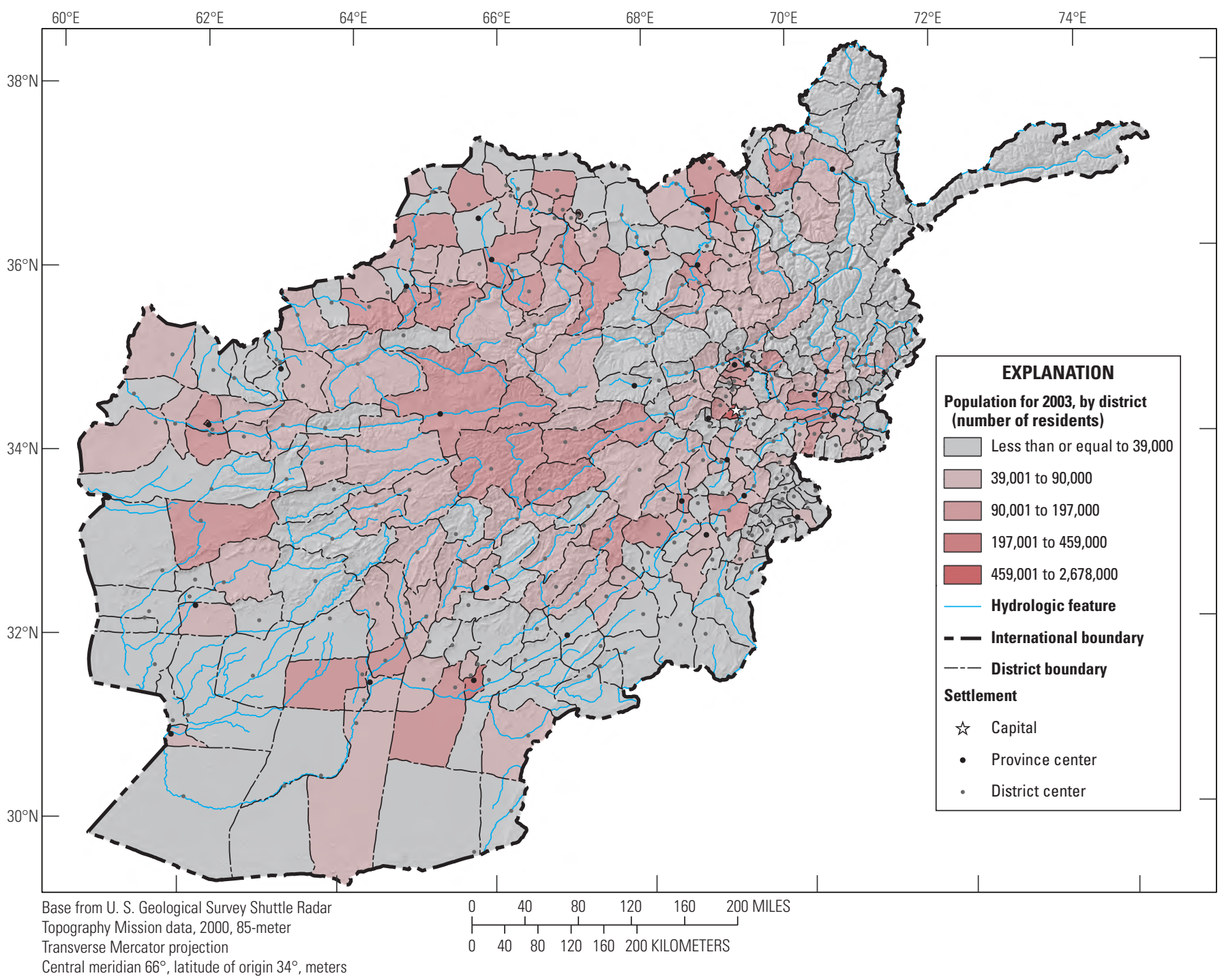

Central meridian $66^{\circ}$, latitude of origin $34^{\circ},{ }^{\circ}$

Figure 2. Choropleth map showing the 2003 population of Afghanistan, by district. 


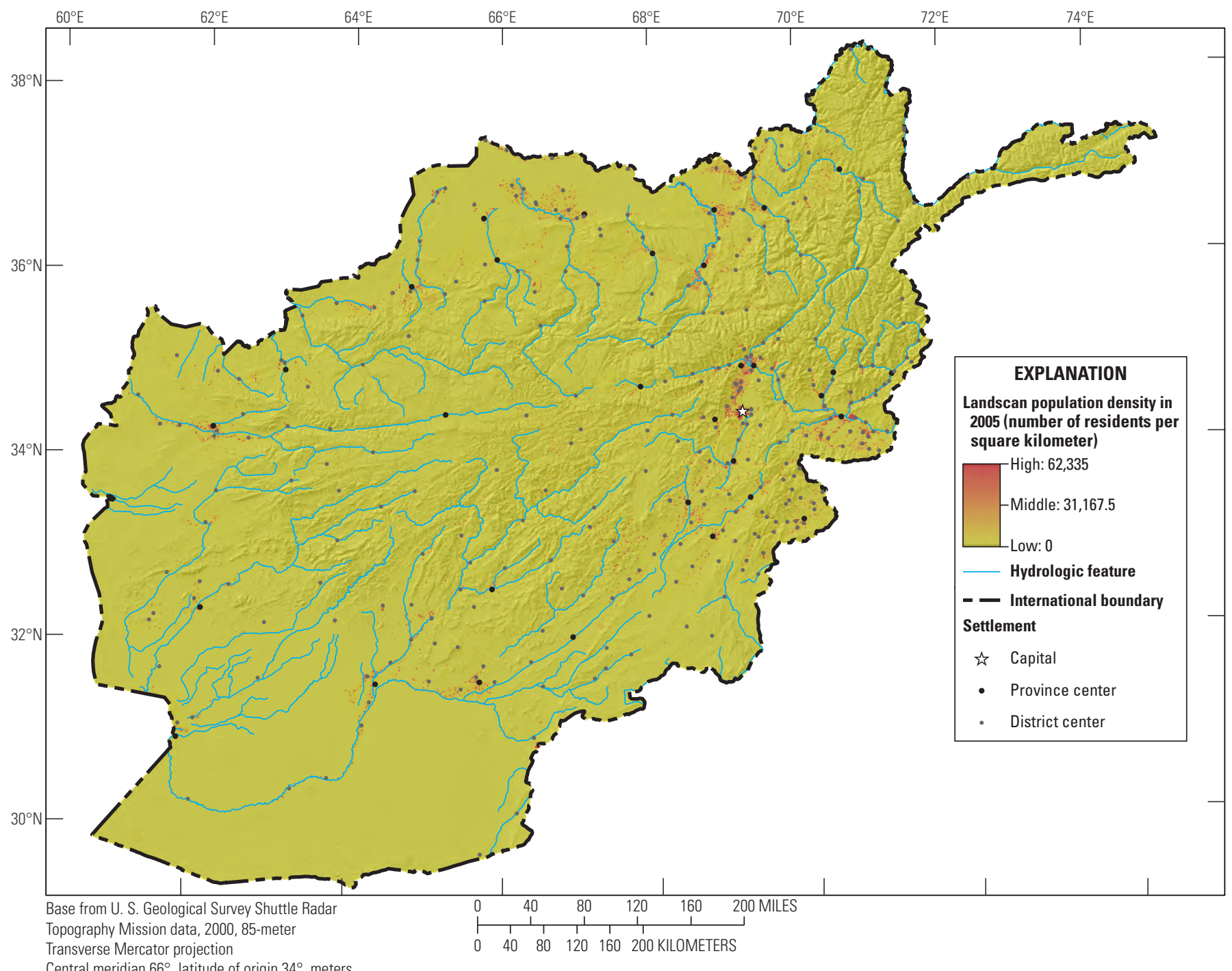

Central meridian $66^{\circ}$, latitude of origin $34^{\circ}$, meters

Datum: World Geodetic System 1984 (WGS 84)

Figure 3. Map showing the ambient population distribution within Afghanistan (beyond the province and district centers) based on 2005 Landscan raster data, the distribution of major settlements (province and district centers), and hydrologic features (rivers and streams). 


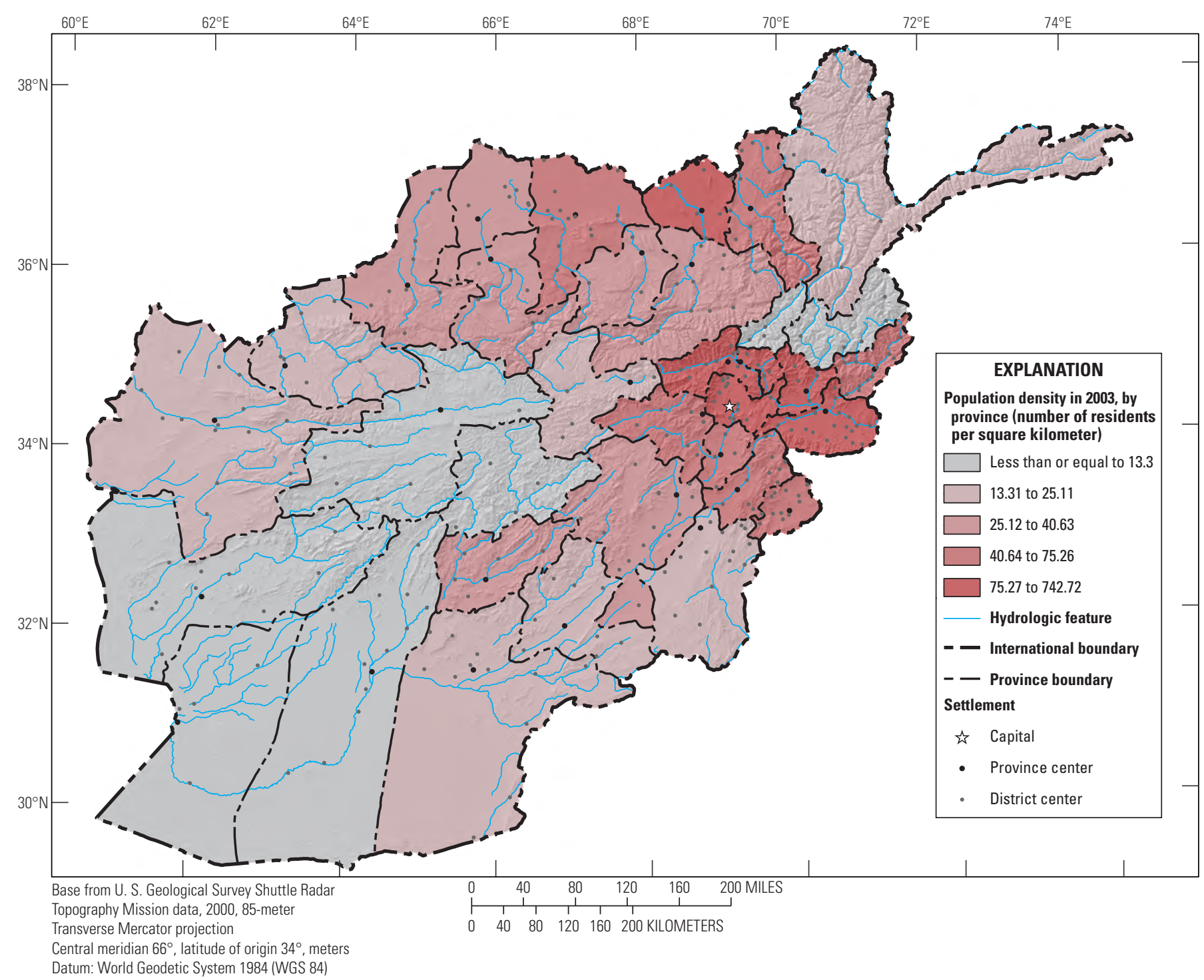

Figure 4. Choropleth map showing population density within Afghanistan, by province, derived from the 2003 data on population by province shown in figure 1 . 


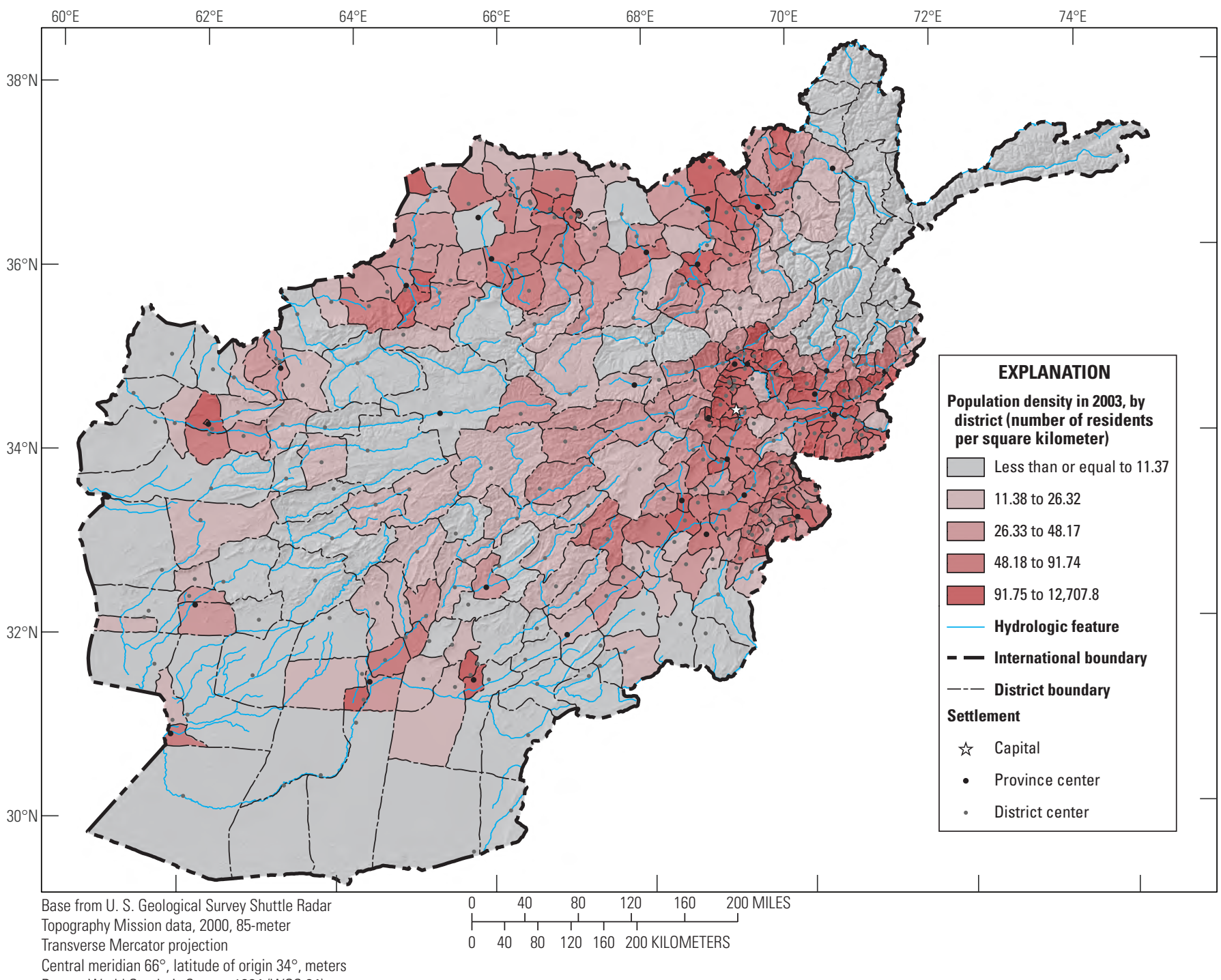

Figure 5. Choropleth map showing population density within Afghanistan, by district, derived from the 2003 data on population by district shown in figure 2. 


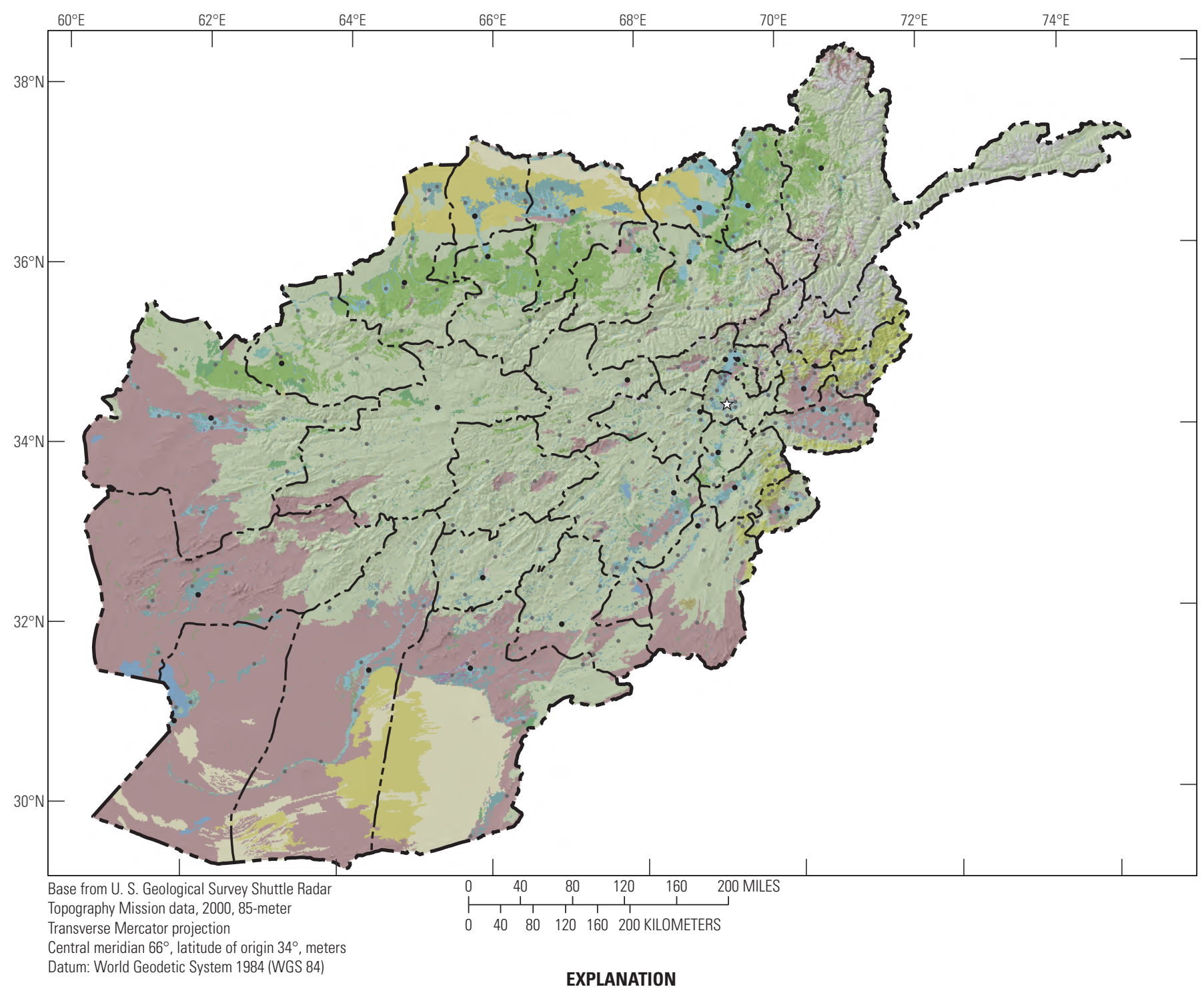

Land-use and land-cover classes-Based on Automated Information Mapping System (AIMS) data

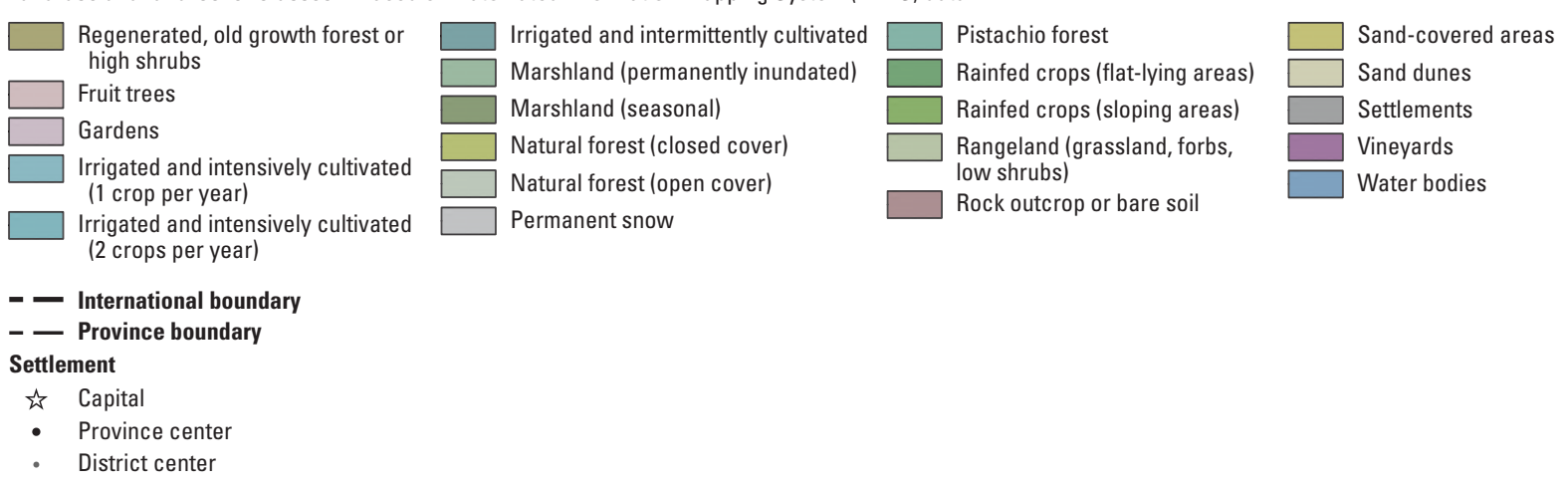

Figure 6. Land-use and land-cover classification map of Afghanistan, based on data from the Afghanistan Information Management Services (AIMS). 


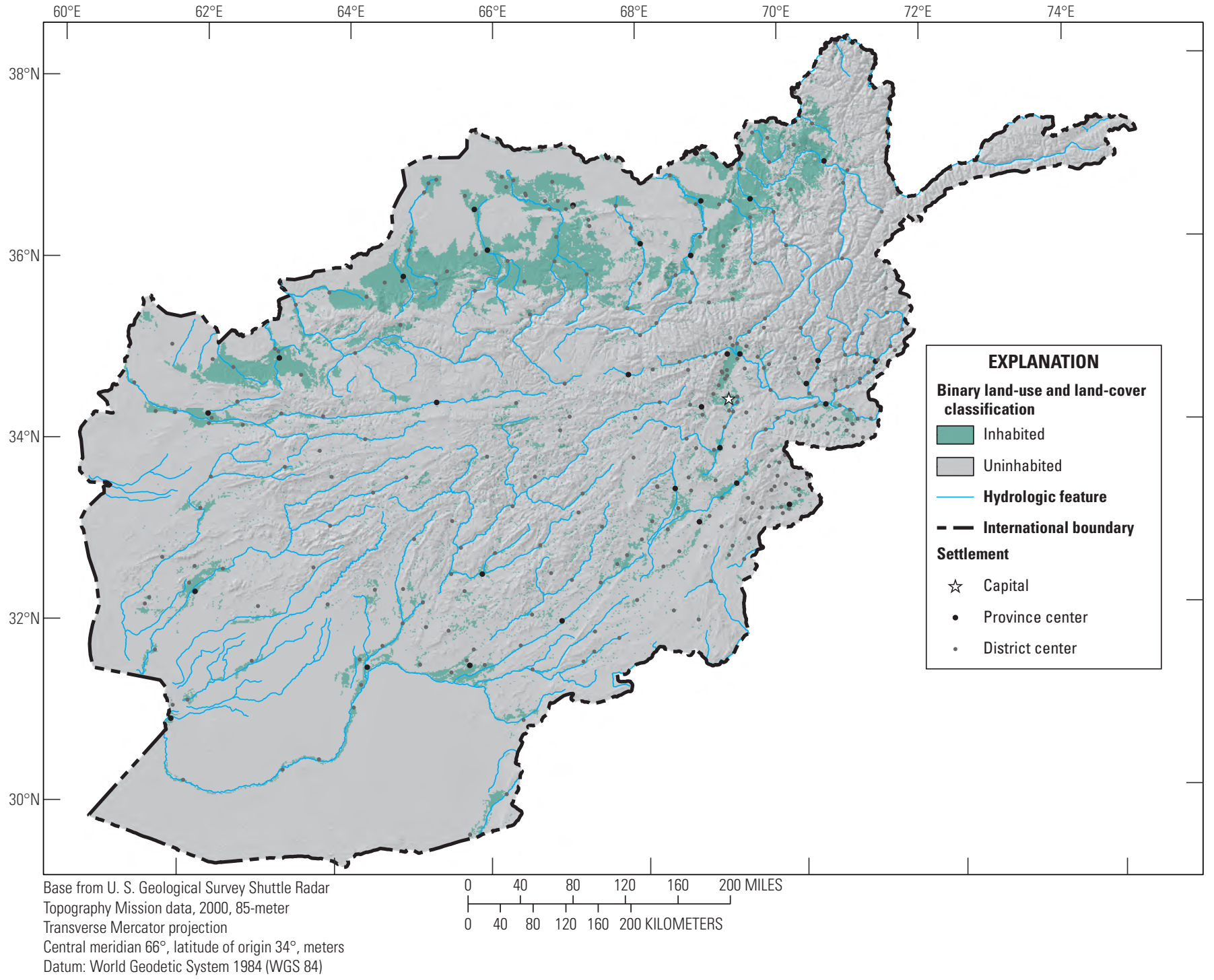

Figure 7. Map of Afghanistan showing inhabited and uninhabited areas, which were based on land-use and land-cover classifications (fig. 6). 


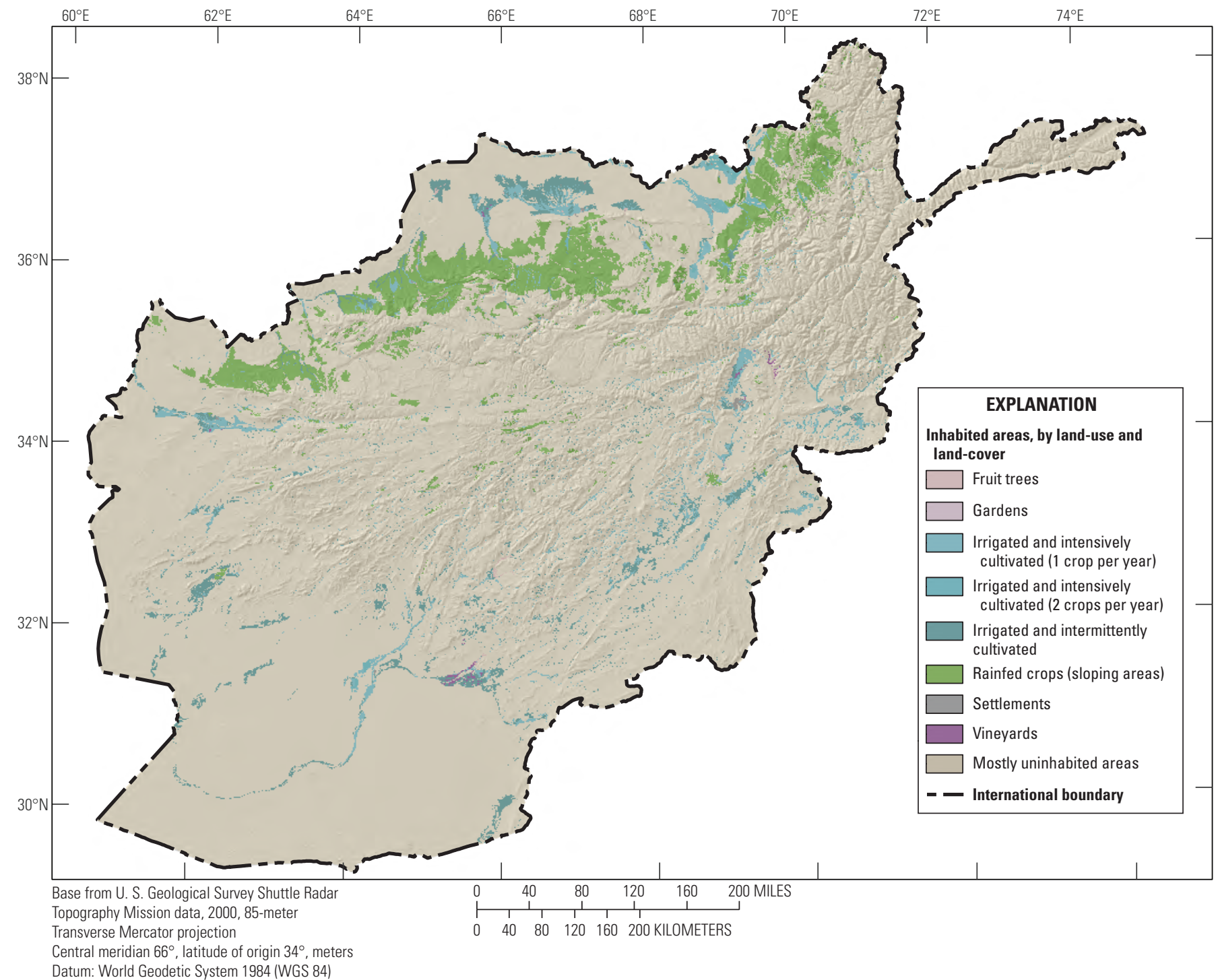

Figure 8. Map of Afghanistan showing inhabited land (fig. 7) by land-use and land-cover classification (fig. 6). 


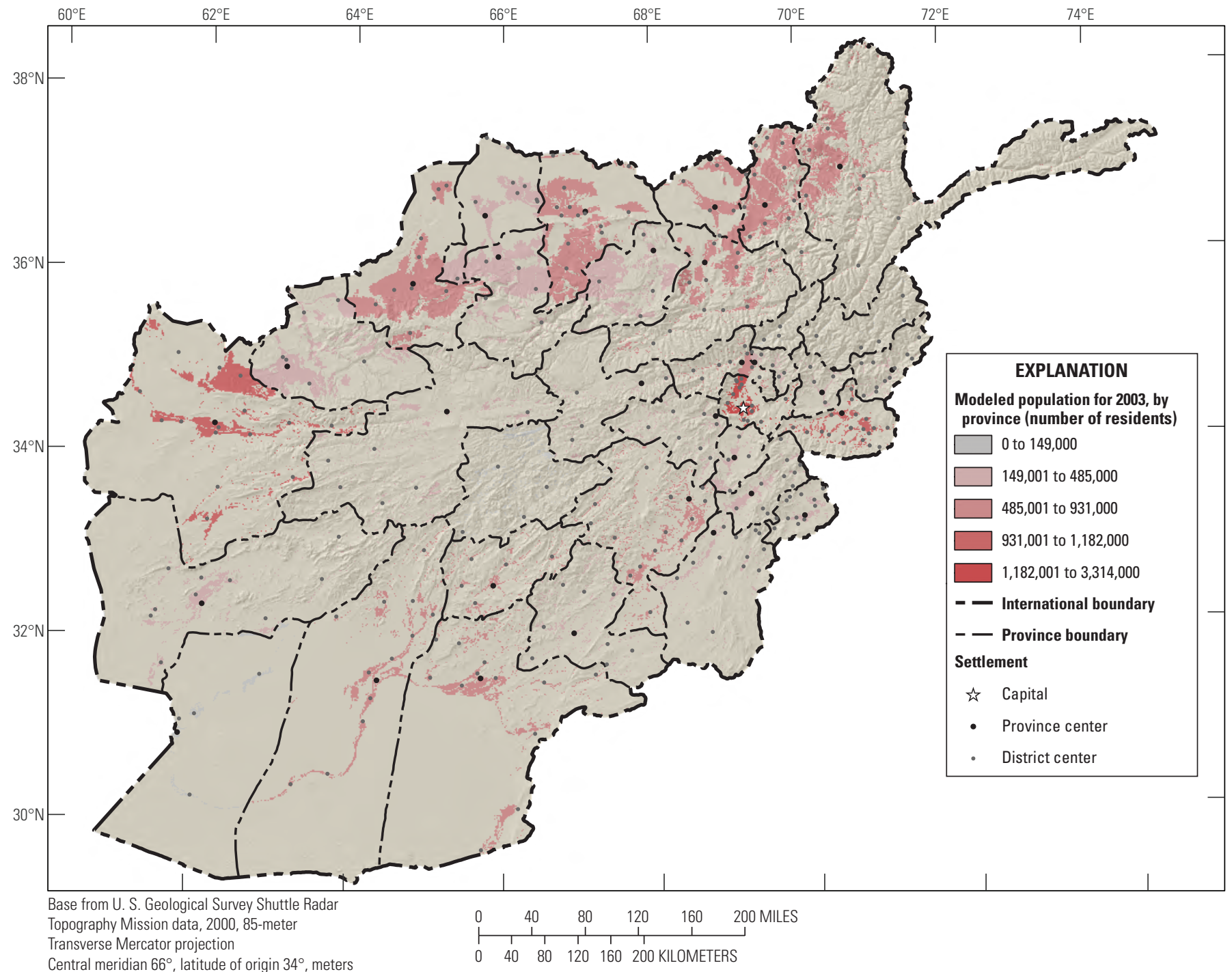

Central meridian $66^{\circ}$, latitude of origin $34^{\circ}$, meters

Datum: World Geodetic System 1984 (WGS 84)

Figure 9. Map of the 2003 population of Afghanistan, by province, compiled using dasymetric mapping methods. 


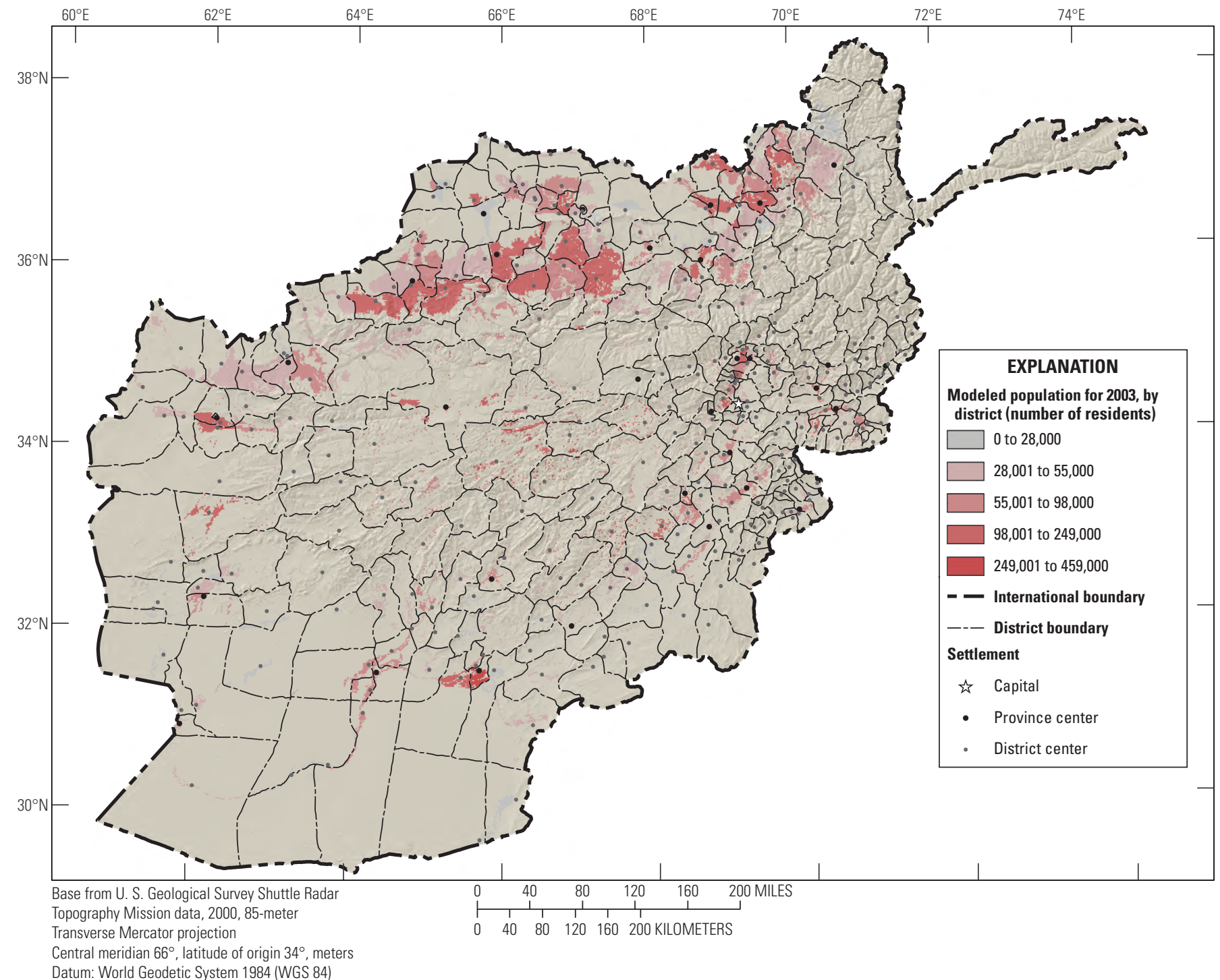

Figure 10. Map of the 2003 population of Afghanistan, by district, compiled using dasymetric mapping methods. 


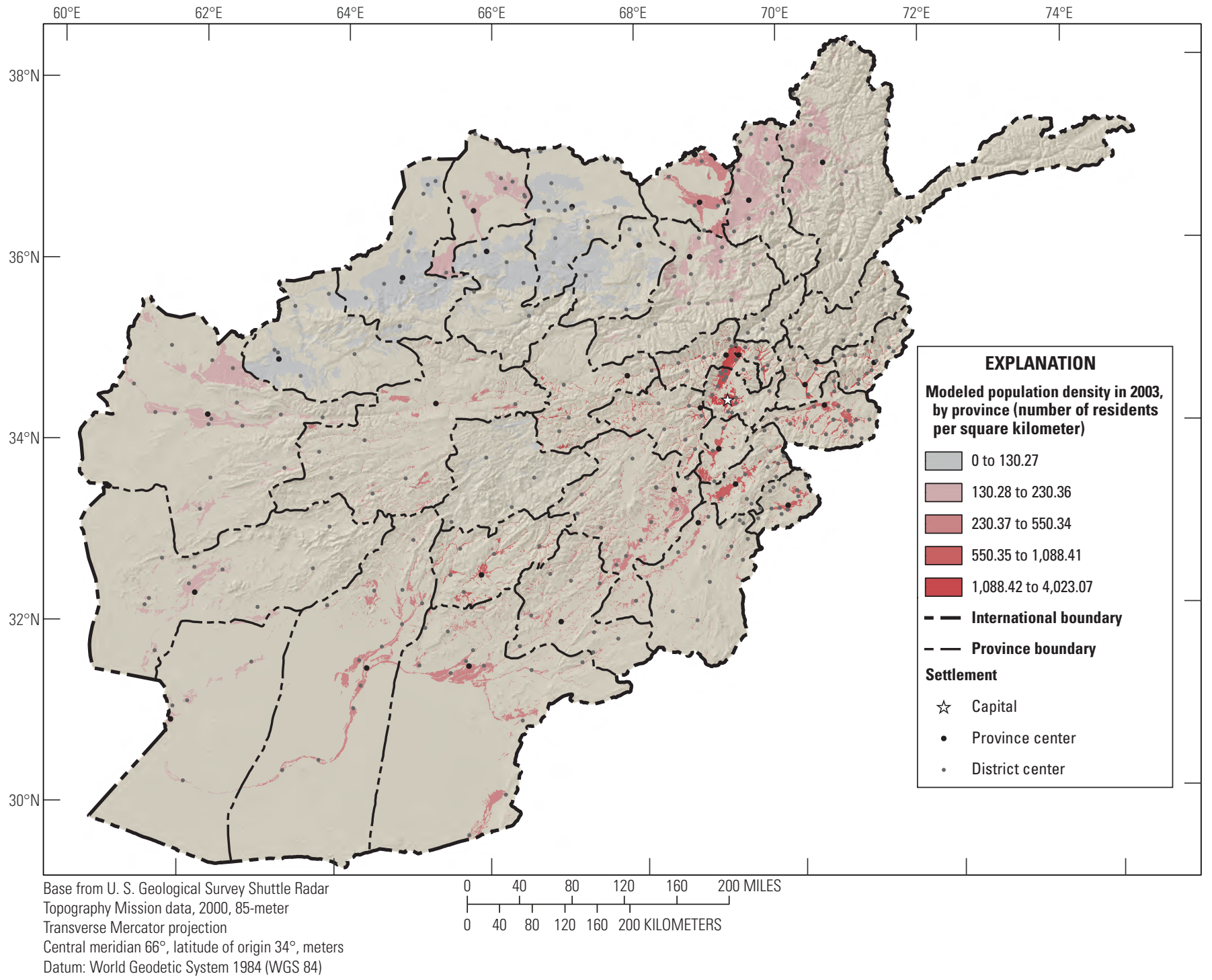

Figure 11. Map of the 2003 population density within Afghanistan, by province, compiled using dasymetric mapping methods. 


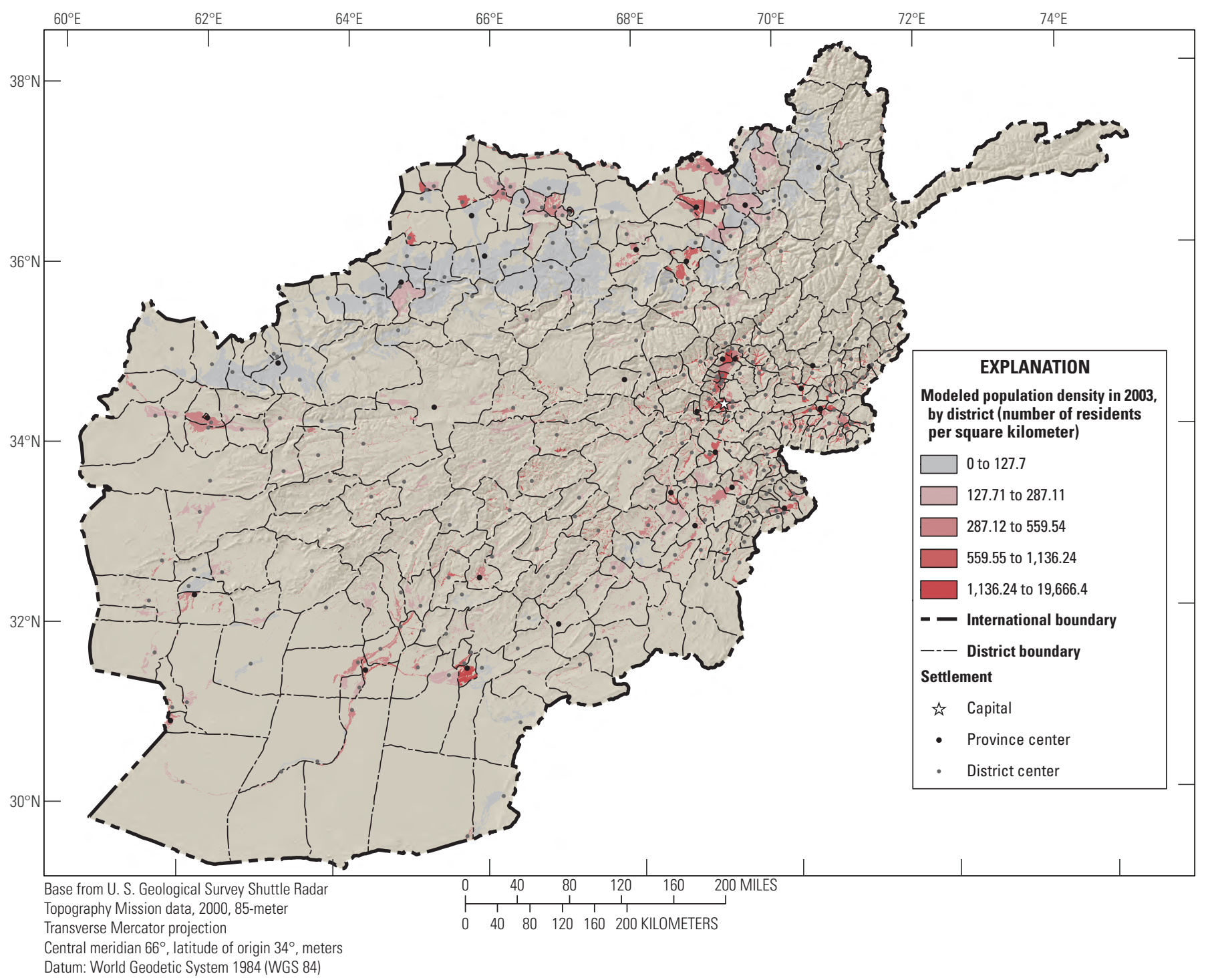

Figure 12. Map of the 2003 population density within Afghanistan, by district, compiled using dasymetric mapping methods. 


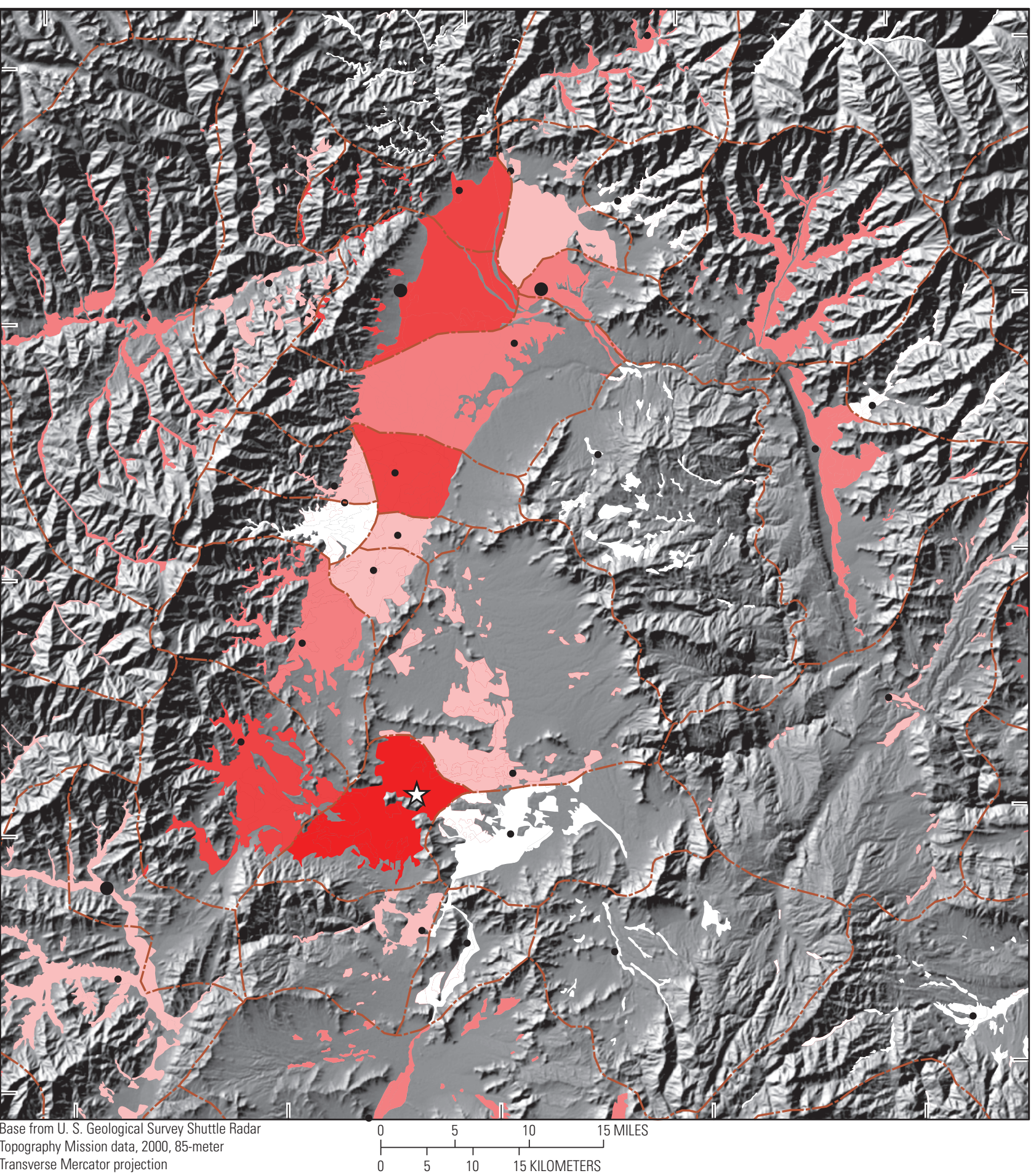

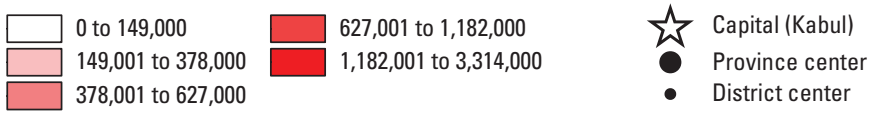

Figure 13. Maps of the Kabul basin of Afghanistan comparing the results of dasymetric population mapping with Landscan population mapping. $A$, Results of combining the province- and district-level dasymetric mapping of the 2003 population (shown separately in figures 9 and 10) with a shaded-relief topographic image from the Shuttle Radar Topography Mission (SRTM) as the base map. $B$, Results of combining the 2005 Landscan population (shown in figure 3) with the same shaded-relief SRTM topographic image. 
B $68^{\circ} 45^{\prime} \mathrm{E} \quad 69^{\circ} \mathrm{E} \quad 69^{\circ} 15^{\prime} \mathrm{E}$ $69^{\circ} 30^{\prime} \mathrm{E} \quad 69^{\circ} 45^{\prime} \mathrm{E}$

$35^{\circ} 15^{\prime} \mathrm{N}$

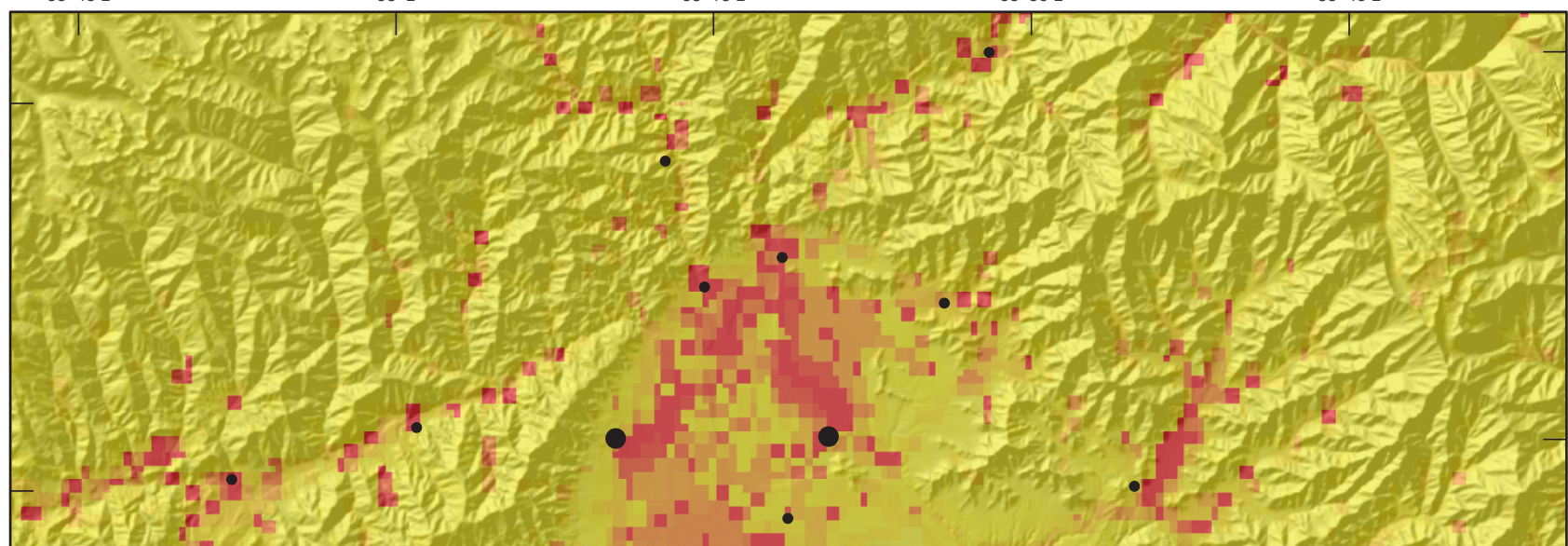

\section{$34^{\circ} 45^{\prime} \mathrm{N}$}

$34^{\circ} 15^{\prime} \mathrm{N}$

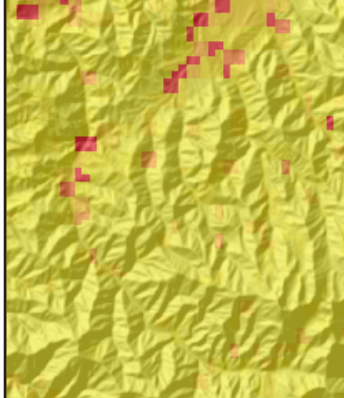

$34^{\circ} 30^{\prime} \mathrm{N}$

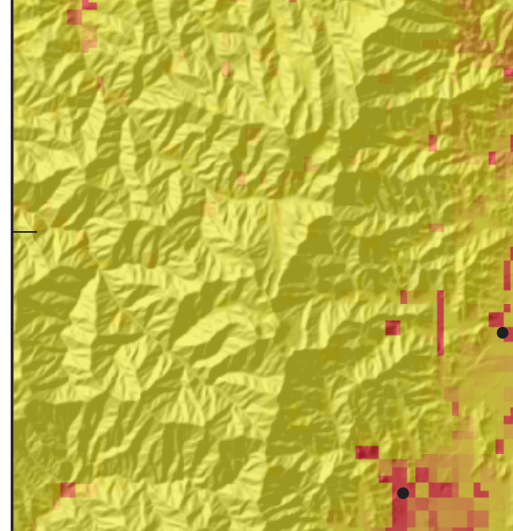

Topography Mission data, 2000, 85-meter

Transverse Mercator projection

Central meridian $66^{\circ}$, latitude of origin $34^{\circ}$, meters

Datum: World Geodetic System 1984 (WGS 84)

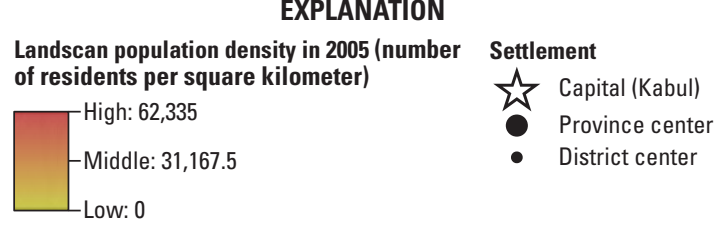

Figure 13. Maps of the Kabul basin of Afghanistan comparing the results of dasymetric population mapping with Landscan population mapping. $A$, Results of combining the province- and district-level dasymetric mapping of the 2003 population (shown separately in figures 9 and 10) with a shaded-relief topographic image from the Shuttle Radar Topography Mission (SRTM) as the base map. $B$, Results of combining the 2005 Landscan population (shown in figure 3) with the same shaded-relief SRTM topographic image.-Continued 
Manscript approved on December 20, 2013

For additional information regarding this publication, contact:

Director, Eastern Mineral and Environmental Resources Science Center U.S. Geological Survey

12201 Sunrise Valley Drive

954 National Center

Reston, VA 20192

Or visit the USGS Eastern Mineral and Environmental Resources Science Center Web site at:

http://minerals.usgs.gov/east/index.html

Edited and prepared by:

USGS Science Publishing Network

Denver, Raleigh, and Reston Publishing Service Centers James E. Banton, layout and illustrator Jeffery Hartley, cartographer Elizabeth D. Koozmin, editor 
